\title{
PULMONARY FUNCTION TESTS OF FEMALES WORKING AT CONSTRUCTION SITES
}

\author{
Neera Goel1 ${ }^{1}$ Niraj Kumar Yadav²
}

${ }_{1}^{1}$ Associate Professor, Department of Physiology, GS Medical College and Hospital, Hapur, Uttar Pradesh.

2Tutor, Department of Community Medicine, GS Medical College and Hospital, Hapur, Uttar Pradesh.

\section{BACKGROUND}

ABSTRACT

Respiratory disorders are among the most common occupational diseases. Millions of people are working daily in dusty environment. They are exposed to various types of occupational health hazards such as gases, fumes, inorganic and organic dusts which have risk factors in developing occupational lung diseases. Workers engaged in building and construction work are at risk of developing impaired lung function due to exposure to high level of dust generated at the construction site.

Aims and Objectives- This study aimed to assess the effect of exposure to various types of dust at construction site on pulmonary functions of female construction workers.

\section{MATERIALS AND METHODS}

The pulmonary function test was studied in 110 female construction workers and 110 female control subjects. The subjects were matched for age, height and weight. The Forced Vital Capacity (FVC) measured by simple spirometer and Peak Expiratory Flow Rate (PEFR) by Wright, peak flow meter and results were compared by student's unpaired ' $t$ ' test.

\section{RESULTS}

The results of the present study showed a significant decrease in observed FVC Group 3, 4 and 5, \% FVC in Group 4 and 5, PEFR in Group 4 and 5, and \% PEFR shows significant decrease in Group 3, 4 and 5 of female construction workers. FVC and PEFR are lower than the predictive value in all the groups of female construction workers. Female construction workers showed development of obstructive type of lung function impairment after 9 years of work and restrictive type of lung function impairment after 15 years of work.

\section{CONCLUSION}

Based on the results of the present study, it may be concluded that female construction workers in India are at increased risk of developing occupation related pulmonary impairment. We recommend they should use protective equipment during work.

\section{KEYWORDS}

Pulmonary Function Test, FVC, \% FVC, PEFR, \% PEFR, Female Construction Workers.

HOW TO CITE THIS ARTICLE: Goel N, Yadav NK. Pulmonary function tests of females working at construction sites. J. Evolution Med. Dent. Sci. 2018;7(18):2246-2251, DOI: $10.14260 /$ jemds/2018/506

\section{BACKGROUND}

The lungs are the only vital organ in direct contact with the external environment. Its function is to provide oxygen to the blood and remove carbon dioxide. The air passes through the trachea, bronchi and bronchioles and then finally reaches the alveoli. The most important function of the respiratory passageways is to keep them patent to allow easy passage of the air, to and from the alveoli. The entire surface of the respiratory passage from nose to terminal bronchiole is lined with ciliated epithelium. These cilia beat continuously at a rate of 10 - 20 times per second, the power stroke is always upwards, but in nose it beats downwards. The dust particles are either swallowed or coughed to the exterior, but the smaller particles between 1 - $5 \mu \mathrm{m}$ settle down in the smaller bronchioles as a result of gravitational precipitation. Smaller dust particles than $1 \mu \mathrm{m}$ in diameter diffuses in the wall of the alveoli and adhere to alveolar fluid. Many of these particles that become entrapped in the alveoli are removed by alveolar

'Financial or Other Competing Interest': None.

Submission 23-03-2018, Peer Review 16-04-2018,

Acceptance 22-04-2018, Published 30-04-2018.

Corresponding Author:

Niraj Kumar Yadav,

House No. 31, Sector-6,

Chiranjeev Vihar, Ghaziabad, Uttar Pradesh.

E-mail: nirajbhu965@gmail.com

DOI: $10.14260 /$ jemds $/ 2018 / 506$ macrophages, and others are carried away by lymphatic drainage. Dust particles which are inhaled and lodged in the lung irritate and set up an inflammatory reaction. Healing of this inflammation causes fibrosis leading to defective oxygen diffusion and impaired lung function.(1) Exposure to ambient particulate, air pollution is associated with increase in morbidity and mortality from respiratory and cardiovascular diseases. (2)

The occupation related lung diseases are more likely due to the deposition of dust in lungs and period of exposure, concentration and size of the airborne dust particles in the breathing zone.(3) Respiratory diseases caused by exposure to mineral dust persist in both developed and developing countries despite substantial knowledge about means of their prevention. Exposure to mineral dust occurs in variety of circumstances. Workers subjected to exposure may be engaged in mineral extraction refinery, quarry tunnelling or construction.(4) Decrease in pulmonary function has been reported in coal miners, grain and flour mill workers, cotton workers, workers exposed to tobacco dust, barley dust, talc dust and quarry workers.(5) But none of the studies has reported about female workers engaged in building construction work in India.

All construction sites produce dust from concrete, silica, cement, asbestos, wood, stone, sand etc. Construction dust is classified as PM-10, i.e. particulate matter less than $10 \mu \mathrm{m}$ in diameter and workers inhale these airborne dust particles at 
construction sites.(6) Percentage of crystalline silica in construction and building materials are sand and sandstone 96-100\%, calcium silicate 50-55\%, aggregate concrete $30 \%$, clay brick $15-27 \%$, cement sheet $10-30 \%$, demolition dust 3$4 \%$ and it is also present in cement dust also.(7) Exposure to silica may cause acute and chronic silicosis, chronic bronchitis and emphysema.(1) Cement dust initially causes mucus hypersecretion followed by lung function impairment, chronic obstructive lung disease, restrictive lung disease, pneumoconiosis etc. $(1,8)$

In occupational respiratory diseases, spirometer is one of the most important diagnostic tools which plays a significant role in the diagnosis and prognosis of these diseases and describes the effect of restriction or obstruction on lung function.(9) Pulmonary function are influenced by many factors like sex, age, height, weight, environment and ethnicity.(10) The severity of the impairment of pulmonary function has been shown to depend on years of exposure.(11)

In India, the construction industry is the second largest and a fast growing sector. Transnational companies have been competing in construction industry since the mid 1990s, engaging in both large public sector infrastructure projects and private sector industrial projects.(12) India's construction labour force is estimated at 30 million people, about half are women. Women account for $51 \%$ of total construction labour.(12) So lots of female workers are engaged in construction sites. I found no study on female construction workers, so I took it as a duty to study their lung function.

The aim of study was to assess the effect of construction site dust exposure on lung function of female workers in construction field with comparison to their age matched female and also to see the effects of long duration exposure of dust on pulmonary function test.

\section{MATERIALS AND METHODS}

This is a descriptive comparative study and the study was undertaken in 110 healthy female worker subjects in building and construction work like masonry, mixing the concrete, plastering etc. We have collected data in construction area, where total number of workers were 500 (Male + Female). Out of them total number of females were 200 and 110 female workers fit for the study. Pulmonary function test was also carried out on age matched with 110 healthy housewives as control group of same area. Control are not doing any type of job like tailoring or in any other industry or in teaching job, just doing their household works. Age of subjects ranges from 26 years to 50 years of age and in following age groupsGroup 1= 26-30 years of age, Group 2=31-35 years of age, Group 3=36-40 years of age, Group $4=41-45$ years of age and Group $5=46-50$ years of age. In each group, the duration of job is also taken as Group 1= 5 years of job, Group 2=9 years of job, Group 3= 15 years of job, Group 4= 20 years of job and Group 5= 25 years of job. In Group 1, number of case (n)=22; Group 2, n= 20; Group 3, n= 22; Group 4, n= 24; Group 5, n= 22 and equal number of controls were taken for each subgroup.

\section{Inclusion Criteria}

Subjects willing to participate for study and working in building and construction throughout the years.

\section{Exclusion Criteria}

Subjects with clinical abnormalities of vertebral column and thoracic cage, anaemia, diabetes mellitus, hypertension, pulmonary tuberculosis and any abdominal or chest surgery would be excluded from the study.

All tests were conducted from July to September, so as to eliminate the seasonal variation on the pulmonary function test.(13) The pulmonary function test was done two hours after the main meal.(14) The pulmonary function test, Forced Vital Capacity (FVC) was recorded by simple spirometer and Peak Expiratory Flow Rate (PEFR) with the help of Wright peak flow meter. Parameter taken into account are observed FVC and PEFR, percent predicted are \% FVC and \% PEFR. Predicted value of FVC and PEFR was calculated only for the obtaining percent predicted FVC and percent predicted PEFR.

Subject's pulmonary status is diagnosed with restrictive impairment, based on the Forced Vital Capacity value below $80 \%$ of predictive value and diagnosis of obstructive impairment was based on a Peak Expiratory Flow Rate (PEFR) value below $75 \%$ of predictive value.(15) The subjects with Forced Vital Capacity value below $80 \%$ and Peak Expiratory Flow Rate (PEFR) value below $75 \%$ of predictive value were labelled as subjects with combined lung impairment.(15)

\section{Statistical Analysis}

The data were entered into the computer and analysed by using the Statistical Package for Social Sciences (SPSS) version 10.0 programs for Windows. Unpaired student's ttest, the means and SD was calculated. The significance value was achieved at $\mathrm{p}<0.05$.

\section{RESULTS}

The anthropometric data for the study of female workers at building and construction site is represented in Table 1 . The female construction workers were matched for age, height and weight with housewives as control. For the purpose of analysis of data, the results are tabulated according to different age group along with duration of exposure of dust at building construction site. All lung function parameters were presented and compared in mean value and 'p' value.

\begin{tabular}{|c|c|c|c|c|}
\hline Group & $\begin{array}{c}\text { Exposed/ } \\
\text { Non-Exposed }\end{array}$ & $\begin{array}{c}\text { Age } \\
\text { (In Years) }\end{array}$ & $\begin{array}{c}\text { Height } \\
\text { (cm) }\end{array}$ & $\begin{array}{c}\text { Weight } \\
\text { (Kg) }\end{array}$ \\
\hline \multirow{2}{*}{$\begin{array}{c}\text { Group-1 } \\
\text { 26-30 years of age } \\
n=22\end{array}$} & $\begin{array}{l}\text { Female construction } \\
\text { workers }\end{array}$ & $\begin{array}{c}\text { Mean }=28.1 \\
S D \pm 1.24\end{array}$ & $\begin{array}{c}\text { Mean }=152.2 \\
\mathrm{SD} \pm 2.76\end{array}$ & $\begin{array}{c}\text { Mean }=50.5 \\
S D \pm 2.03\end{array}$ \\
\hline & Housewife (control) & $\begin{array}{c}\text { Mean }=27.8 \\
\mathrm{SD} \pm 1.45 \\
\mathrm{P} \text { value }>0.05\end{array}$ & $\begin{array}{c}\text { Mean }=154.1 \\
\mathrm{SD} \pm 2.99 \\
\mathrm{P} \text { value }>0.05\end{array}$ & $\begin{array}{c}\text { Mean }=55.6 \\
\mathrm{SD} \pm 1.55 \\
\mathrm{P} \text { value }>0.05\end{array}$ \\
\hline $\begin{array}{c}\text { Group-2 } \\
31-35 \text { years of age }\end{array}$ & $\begin{array}{l}\text { Female construction } \\
\text { workers }\end{array}$ & $\begin{array}{c}\text { Mean }=32.2 \\
\mathrm{SD} \pm 1.38\end{array}$ & $\begin{array}{c}\text { Mean }=152.6 \\
S D \pm 2.29\end{array}$ & $\begin{array}{c}\text { Mean }=53.4 \\
S D \pm 1.98\end{array}$ \\
\hline
\end{tabular}




\begin{tabular}{|c|c|c|c|c|}
\hline $\mathrm{n}=20$ & Housewife (control) & $\begin{array}{c}\text { Mean }=33.0 \\
S D \pm 1.51 \\
\text { P value }>0.05\end{array}$ & $\begin{array}{c}\text { Mean }=154 \\
S D \pm 1.6 \\
\text { P value }>0.05\end{array}$ & $\begin{array}{c}\text { Mean }=54.7 \\
\text { SD } \pm 1.9 \\
\text { P value }>0.05\end{array}$ \\
\hline \multirow[b]{2}{*}{$\begin{array}{c}\text { Group-3 } \\
\text { 36-40 years of age } \\
n=22\end{array}$} & $\begin{array}{l}\text { Female construction } \\
\text { workers }\end{array}$ & $\begin{array}{c}\text { Mean }=37.6 \\
S D \pm 1.63\end{array}$ & $\begin{array}{c}\text { Mean }=154.0 \\
S D \pm 2.16\end{array}$ & $\begin{array}{c}\text { Mean }=54.0 \\
S D \pm 2.04\end{array}$ \\
\hline & Housewife (control) & $\begin{array}{c}\text { Mean }=37.5 \\
S D \pm 1.5 \\
\text { P value }>0.05\end{array}$ & $\begin{array}{c}\text { Mean }=152.8 \\
S D \pm 1.86 \\
\text { P value }>0.05\end{array}$ & $\begin{array}{c}\text { Mean }=58.2 \\
S D \pm 1.91 \\
\text { P value }>0.05\end{array}$ \\
\hline \multirow{2}{*}{$\begin{array}{c}\text { Group- } 4 \\
\text { 41-45 years of age } \\
n=24\end{array}$} & $\begin{array}{l}\text { Female construction } \\
\text { workers }\end{array}$ & $\begin{array}{c}\text { Mean }=42.7 \\
S D \pm 1.28\end{array}$ & $\begin{array}{c}\text { Mean }=151.0 \\
S D \pm 2.07\end{array}$ & $\begin{array}{c}\text { Mean=51.1 } \\
\text { SD } \pm 3.65\end{array}$ \\
\hline & Housewife (control) & $\begin{array}{c}\text { Mean }=43.4 \\
S D \pm 1.28 \\
\text { P value }>0.05\end{array}$ & $\begin{array}{c}\text { Mean }=151.3 \\
S D \pm 1.85 \\
P \text { value }>0.05\end{array}$ & $\begin{array}{c}\text { Mean }=62.2 \\
S D \pm 3.10 \\
\text { P value }>0.05\end{array}$ \\
\hline \multirow{2}{*}{$\begin{array}{c}\text { Group- } 5 \\
\text { 46-50 years of age } \\
n=22\end{array}$} & $\begin{array}{l}\text { Female construction } \\
\text { workers }\end{array}$ & $\begin{array}{c}\text { Mean=48.0 } \\
\mathrm{SD} \pm 1.77\end{array}$ & $\begin{array}{c}\text { Mean }=152.8 \\
\mathrm{SD} \pm 3.18\end{array}$ & $\begin{array}{c}\text { Mean=51.7 } \\
\mathrm{SD} \pm 2.31\end{array}$ \\
\hline & Housewife (control) & $\begin{array}{c}\text { Mean }=48.2 \\
\mathrm{SD} \pm 1.45 \\
\mathrm{P} \text { value }>0.05\end{array}$ & $\begin{array}{c}\text { Mean }=152.5 \\
S D \pm 2.50 \\
P \text { value }>0.05\end{array}$ & $\begin{array}{c}\text { Mean }=62.2 \\
S D \pm 3.15 \\
\text { P value }>0.05\end{array}$ \\
\hline
\end{tabular}

Values are mean SD. *Unpaired ' $\mathrm{t}$ ' test; not significant $(\mathrm{P}>0.05)$; $\mathrm{S}$, significant $(\mathrm{P}<0.01)$

Table 2 shows the comparison of lung function parameter, Forced Vital Capacity in different groups in female construction workers compared with their matched control group (housewife). In Group 1 and 2, FVC in female construction workers are lower than the control, but there was no significant difference in both FVC and \% FVC. In Group 3 significant decrease in FVC and no significant difference in \% FVC and in Group 4 and 5 statistically highly significant decrease in FVC and \% FVC is seen. In Group 4 and 5 , the \% FVC is $78.25 \%$ and $74.5 \%$ (below $80 \%$ ) i.e. suggestive of restrictive type of lung disorder present in female building and construction workers with more than 15 years of duration of work. Observed FVC in all the groups are less than their predictive value and much lower in female construction workers.

\begin{tabular}{|c|c|c|c|c|c|}
\hline & & $\begin{array}{c}\text { FVC }(\mathrm{mL}) \\
\text { Female Construction } \\
\text { Worker }\end{array}$ & $\begin{array}{c}\text { FVC }(\mathrm{mL}) \\
\text { Control }\end{array}$ & $\begin{array}{c}\% \text { FVC } \\
\text { Female Construction } \\
\text { Worker }\end{array}$ & $\begin{array}{c}\text { \% FVC } \\
\text { Control }\end{array}$ \\
\hline $\begin{array}{c}\text { Group-1 } \\
5 \text { years } \\
n=22\end{array}$ & $\begin{array}{l}\text { Mean SD } \\
t= \\
\text { p value }\end{array}$ & $\begin{array}{c}2333 \\
+225.76 \\
0.83 \\
>0.05\end{array}$ & $\begin{array}{c}2416 \\
\pm 199.14\end{array}$ & $\begin{array}{c}92.8 \\
+9.26 \\
0.144 \\
>0.05\end{array}$ & $\begin{array}{r}93.4 \\
\pm 8.3\end{array}$ \\
\hline $\begin{array}{l}\text { Group- } 2 \\
9 \text { years } \\
n=20\end{array}$ & $\begin{array}{l}\text { Mean SD } \\
t= \\
\mathrm{p} \text { value }\end{array}$ & $\begin{array}{c}2201 \\
+223.71 \\
1.67 \\
>0.05\end{array}$ & $\begin{array}{c}2357 \\
+80.66\end{array}$ & $\begin{array}{c}89.4 \\
+8.46 \\
1.58 \\
>0.05\end{array}$ & $\begin{array}{r}94.8 \\
\pm 3.3\end{array}$ \\
\hline $\begin{array}{l}\text { Group- } 3 \\
15 \text { years } \\
n=22\end{array}$ & $\begin{array}{l}\text { Mean SD } \\
\quad t= \\
p \text { value }\end{array}$ & $\begin{array}{c}2026 \\
+158.32 \\
3.89 \\
<0.05\end{array}$ & $\begin{array}{r}2293 \\
\pm 58.5\end{array}$ & $\begin{array}{c}85.9 \\
+7.46 \\
3.53 \\
=0.05\end{array}$ & $\begin{array}{c}96.1 \\
\pm 1.57\end{array}$ \\
\hline $\begin{array}{c}\text { Group } 4 \\
20 \text { years } \\
n=24\end{array}$ & $\begin{array}{l}\text { Mean SD } \\
t= \\
p \text { value }\end{array}$ & $\begin{array}{c}1731 \\
+212.69 \\
5.81 \\
<0.001\end{array}$ & $\begin{array}{c}2234 \\
\pm 127.55\end{array}$ & $\begin{array}{l}78.25 \\
+9.3 \\
4.74 \\
<0.05\end{array}$ & $\begin{array}{c}93.1 \\
\pm 4.46\end{array}$ \\
\hline $\begin{array}{l}\text { Group } 5 \\
25 \text { years } \\
n=22\end{array}$ & $\begin{array}{l}\text { Mean SD } \\
t= \\
p \text { value }\end{array}$ & $\begin{array}{c}1583 \\
\pm 237.29 \\
6.28 \\
<0.001\end{array}$ & $\begin{array}{c}2178 \\
\pm 122.6\end{array}$ & $\begin{array}{c}74.5 \\
+9.99 \\
5.59 \\
<0.001\end{array}$ & $\begin{array}{r}92.8 \\
\pm 6.17\end{array}$ \\
\hline
\end{tabular}

Values are mean SD. *Unpaired ' $\mathrm{t}$ ' test; not significant $(\mathrm{P}>0.05)$; significant $(\mathrm{P}<0.05)$; highly significant $(\mathrm{P}<0.001)$. 


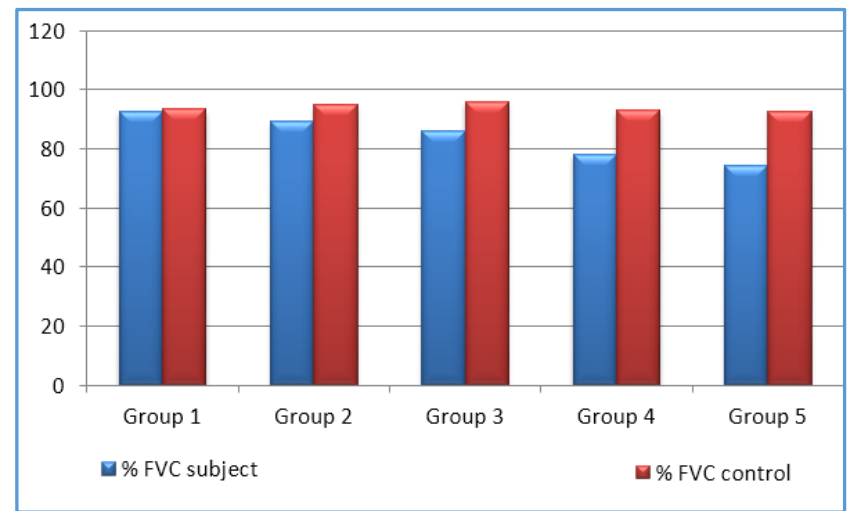

Graph showing Comparison of \% Force Vital Capacity

Table 3 shows the comparison of pulmonary function parameter- Peak Expiratory Flow Rate, observed value, predicted value and \% PEFR in different groups in female building and construction workers compared with their matched control group. In all the groups, the observed PEFR and \% PEFR in female construction workers were less than the control. In Group 1, 2 and 3, there was no significant decrease in observed PEFR and in Group 4 and 5 significant decreases in observed PEFR. In Group 3, 4 and 5 statistically significant decrease were seen in \% PEFR. In Group 3, 4 and 5 , \% PEFR is $72.8 \%, 66.6 \%$ and $58.8 \%$ in female construction workers (below $75 \%$ of predictive value) suggestive of obstructive type of lung disorder occurring after 9 years of exposure and becomes worse after more years of exposure. But in control group, 5\% PEFR (69.3\%) is also below 75\% of predictive value meaning as age advances PEFR may decrease due to other causes. In all the groups observed, PEFR is less than predicted PEFR value.

\begin{tabular}{|c|c|c|c|c|c|}
\hline \multirow{2}{*}{$\begin{array}{c}\text { Group/ } \\
\text { Duration of Job }\end{array}$} & & \multicolumn{2}{|c|}{ PEFR (in ml/sec) } & \multicolumn{2}{|c|}{ \% PEFR } \\
\hline & & $\begin{array}{c}\text { Female Construction } \\
\text { Worker }\end{array}$ & Control & $\begin{array}{c}\text { Female Construction } \\
\text { Worker }\end{array}$ & Control \\
\hline $\begin{array}{c}\text { Group-1 } \\
5 \text { years } \\
n=22\end{array}$ & $\begin{array}{l}\text { Mean SD } \\
t= \\
p \text { value }\end{array}$ & $\begin{array}{c}387 \\
+39.25 \\
0.12 \\
>0.05 \\
\end{array}$ & $\begin{array}{c}410 \\
\pm 37.6\end{array}$ & $\begin{array}{c}83.5 \\
+8.24 \\
0.5 \\
>0.05 \\
\end{array}$ & $\begin{array}{c}85.3 \\
\pm 8.46\end{array}$ \\
\hline $\begin{array}{c}\text { Group-2 } \\
9 \text { years } \\
n=20\end{array}$ & $\begin{array}{l}\text { Mean SD } \\
t= \\
p \text { value }\end{array}$ & $\begin{array}{c}390 \\
\pm 57.35 \\
0.45 \\
>0.05 \\
\end{array}$ & $\begin{array}{c}428 \\
+56.75\end{array}$ & $\begin{array}{c}84.5 \\
\pm 11.9 \\
1.32 \\
>0.05 \\
\end{array}$ & $\begin{array}{c}86.2 \\
+11.63\end{array}$ \\
\hline $\begin{array}{l}\text { Group-3 } \\
15 \text { years } \\
n=22\end{array}$ & $\begin{array}{l}\text { Mean SD } \\
t= \\
p \text { value }\end{array}$ & $\begin{array}{c}336 \\
\pm 38.8 \\
1.87 \\
>0.05 \\
\end{array}$ & $\begin{array}{c}397 \\
+13.45\end{array}$ & $\begin{array}{c}72.8 \\
\pm 9.5 \\
1.33 \\
<0.05 \\
\end{array}$ & $\begin{array}{c}86.7 \\
\pm 2.23\end{array}$ \\
\hline $\begin{array}{c}\text { Group- } 4 \\
20 \text { years } \\
n=24\end{array}$ & $\begin{array}{l}\text { Mean SD } \\
t= \\
p \text { value }\end{array}$ & $\begin{array}{c}285 \\
+40.36 \\
2.51 \\
<0.05 \\
\end{array}$ & $\begin{array}{c}331 \\
\pm 34.82\end{array}$ & $\begin{array}{c}66.6 \\
+12.3 \\
2.42 \\
<0.05\end{array}$ & $\begin{array}{r}79 \\
+7.89\end{array}$ \\
\hline $\begin{array}{c}\text { Group-5 } \\
25 \text { years } \\
n=22\end{array}$ & $\begin{array}{c}\text { Mean SD } \\
t= \\
p \text { value }\end{array}$ & $\begin{array}{c}251 \\
\pm 46.7 \\
2.06 \\
<0.05\end{array}$ & $\begin{array}{c}300 \\
+38.1\end{array}$ & $\begin{array}{c}58.5 \\
\pm 9.2 \\
3.18 \\
<0.05\end{array}$ & $\begin{array}{c}69.3 \\
+5.28\end{array}$ \\
\hline \multicolumn{6}{|c|}{ Table 3. Comparison of PEFR, \% PEFR in all groups Compared with their Matched Controls } \\
\hline
\end{tabular}

Values are mean SD. *Unpaired ' $t$ ' test; not significant $(\mathrm{P}>0.05)$; significant $(\mathrm{P}<0.05)$; Highly significant $(\mathrm{P}<0.001)$.

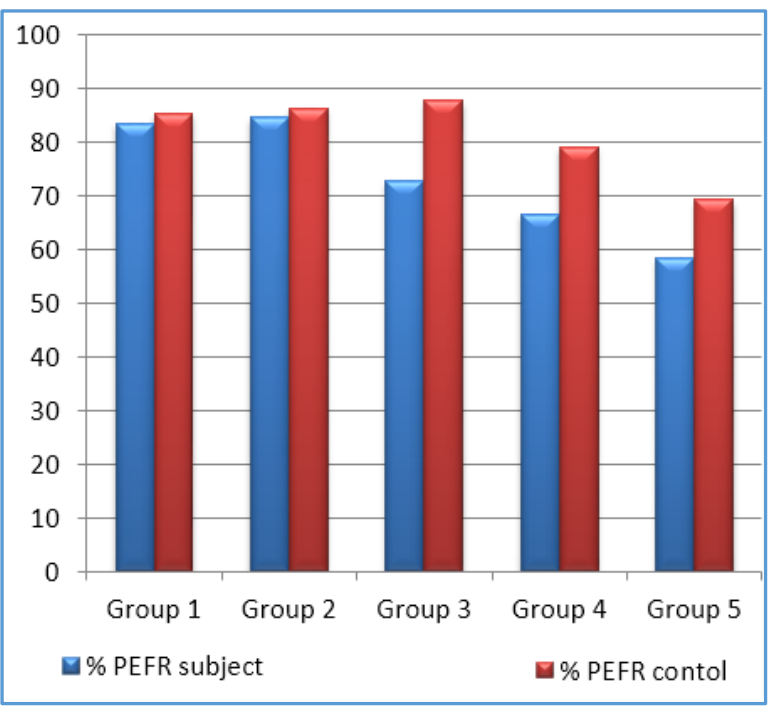

Graph showing Comparison of \% PEFR

\section{DISCUSSION}

Occupational respiratory diseases are usually caused by extended exposure to irritating or toxic substances that may cause acute or chronic respiratory ailments.(16) Work-related disorders are the major cause for complaints and disability in worker population. The main problem encountered in the environment is the respirable dust $(<10 \mu \mathrm{m})$. When fine dust enters the respiratory system, the human body considers it to be foreign material, which the body should be defended against. Exposure to ambient particulate air pollution is associated with increase in morbidity and mortality from respiratory and cardiovascular diseases. Individuals working in dusty environment face the risk of inhaling particulate materials that may lead to adverse respiratory effects. All construction sites generate high level of dust typically from concrete, silica, asbestos and cement, wood, stone, sand and the workers are exposed to this airborne dust. Dust and cement particles which are inhaled are lodged in the lung and 
causes lung irritation, mucus hypersecretion initially followed by lung function impairment, lung inflammation, chronic obstructive lung disease, restrictive lung disease, pneumoconiosis and so on.[1,8,14]

In my study, the pulmonary function tests show significant decrease in observed FVC in Group 3, 4 and 5, \% FVC in Group 4 and 5, PEFR in Group 4 and 5, \% PEFR shows significant decrease in Group 3,4 and 5 of female construction workers. FVC and PEFR are lower than the predictive value in all the groups. After 9 years of cement dust exposure, obstructive type of lung impairment was seen and after 15 years of exposure, development of restrictive type of lung impairment was observed. There were chances of development of both type of lung function impairment. My reports are supported by various studies conducted from time to time by other researchers.

In a study by $\mathrm{S}$. Smilee Johney, pulmonary function parameters like FVC, $\mathrm{FEV}_{1}$, \% $\mathrm{FEV}_{1}$ / FVC, PEFR and $\mathrm{FEF}_{25-75 \%}$ was adversely affected in construction workers and caused an obstructive pattern of lung function impairment.(17) $\mathrm{L}$. Christine Oliver and his colleagues studied the lung function of workers in highway construction work and found that FEV1 in these workers are lower than the predicted value and are at increased risk for asthma.(18)

Green et al demonstrated the effect of long-term exposure to mineral dust in young Indian adults and showed that FVC was significantly lower in this group compared to control group.(19)

Bagatin et al analysed the influence of exposure time to silica on pulmonary function of stone quarry workers and found that the FVC, FEV1, \% FEV1/ FVC are reduced in exposure group and peripheral airways are involved first and if the duration of exposure is increased, large airways are also involved.(20)

Chia KS and his co-workers in their study showed that small airway obstruction is seen in the absence of radiological evidence.(21) Chun Yuh Yang et al assessed the relationship between cement dust exposure and ventilatory function in the workers and showed that cement dust may lead to high prevalence of chronic respiratory disease and the reduction of lung capacities. They found out that the exposed workers had reduced FVC, FEV1 and FEF (25-75\%).(22)

Al-Neaimi along with his colleagues observed that pulmonary functions like FVC, FEV1, FEV1/ FVC and PEFR were significantly reduced in the cement factory workers in a rapidly developing country.(23) In study of Sultan Ayoub Meo et al found a duration response effect and shows that longterm exposure to cement dust prominently decreased the pulmonary function. Cement factory workers with duration of exposure greater than 10 years showed a significant reduction in FVC, FEV1, PEF and MVV relative to their matched controls. (24)

The dust that are floating in their vicinity due to various construction activity enter into their respiratory pathway through nose and mouth leading to chronic respiratory disease and the reduction of lung capacities. $(25,26)$

Mathur ML reported a decreased PEFR in the workers exposed to silica in comparison to healthy adults.(27) The workers in the construction site and sweeping environment adversely affect their pulmonary function parameters like
FVC, FEV1, FEV1/ FVC\%, PEFR and FEF resulting in the obstructive pattern of lung function impairment, which is associated with the years of exposure and airborne dust in the work site.(28)

In a study of El Badari and Saeed, a significant reduction in FVC, FEV1 and PEFR in cement dust exposed workers compared to control was reported.(11)

Mark Purde et al found that impaired lung functions, which may be obstructive or restrictive are associated with dust exposure in the construction workers.(8)

\section{CONCLUSION}

The present study concluded that in female workers at construction sites, pulmonary function parameters like FVC, $\%$ FVC, PEFR and \% PEFR are negatively affected due to airborne particulate material. In the female construction workers, obstructive type of lung diseases develop early, then long duration of work at construction site develops restrictive type of lung diseases. This concluded that building material dust damages the lungs. So, we recommend that workers should learn to use protective facemasks at construction sites and use other measures to reduce dust flow into the environment like spraying water to settle down the dust and reduce the lung disease burden in the community.

\section{ACKNOWLEDGEMENTS}

Thanks to all the hardworking female construction workers who made this project successful with their cooperation.

\section{REFERENCES}

[1] Kasper DL, Braunwald E, Fauci AS, et al. Environmental lung diseases. In: Harrison's principles of Internal Medicine. Vol. 2. 16 th edn. New York: McGraw-Hill 2008;15: p. 21-7.

[2] Godleski JJ, Verrier RL, Koutrakis P, et al. Mechanisms of morbidity and mortality from exposure to ambient air particles. Res Rep Health Eff Inst 2000;(91):5-88, 89-103.

[3] Mengesha YA, Bekele A. Relative chronic effects of occupational dusts on respiratory indices and health of workers in three Ethiopian factories. Am J Ind Med 1998;34(4):373-80.

[4] Wang Z, Dong D, Liang X, et al. Cancer mortality among silicosis in China's metallurgical industry. Int J Epidemiol 1996;25(5):913-7.

[5] Garshick E, Schenker MB, Dosman JA. Occupationally induced airway obstruction. Med Clin North Am 1996;80(4):851-78.

[6] Nij TE, Hilhorst S, Spee T, et al. Dust control measures in the construction industry. Ann Occup Hyg 2003;47(3):211-8.

[7] Seaton A. Silicosis. In: Morgan WKC, Seaton A, eds. Occupational lung diseases. $3^{\text {rd }}$ edn. Philadelphia: WB Saunders 1995: p. 222-37.

[8] Purdue MP, Gold L, Järvholm B, et al. Impaired lung function and lung cancer incidence in a cohort of Swedish construction workers. Thorax 2007;62(1):516. 
[9] Wagner NL, Beckett WS, Steinberg R. Using spirometry results in occupational medicine and research: common errors and good practice in statistical analysis and reporting. Indian J Occup \& Environ Med 2006;10(1):5-10.

[10] Mashalla YJ, Mesesa PC, Veenekalaas RJ. Changing relationship between FEV1 and height during adolescence. East Afr Med J 1992;69(5):240-3.

[11] Alakija W, Iyawe VI, Jarikre LN, et al. Ventilatory function of workers at Okpella cement factory in Nigeria. West Afr J Med 1990;9(3):187-92.

[12] Jhabvala R, Kanbur R. Globalization and Economic Reform as Seen from the Ground: SEWA'S, Experience in India. wiego.org >occupational group $>$ construction worker. December 2002.

[13] Hruby, Butler. Determination of progression in sand blaster silicosis: Annals of Occupational Hygiene 1975;26:701-12.

[14] Rao MN, Kashyap SK, Kulkarni PK, et al. Pulmonary function studies in 15-18 years age worker exposed to dust in industries. India J Physiol Pharmacol 1992;36(1):51-4.

[15] Mukhtar MS, Rao GM. Respiratory effects of occupational exposure to asbestos. Indian J Physiol Pharmacol 1996;40(1)98-102.

[16] Park K. Occupational health. In: Park's textbook of preventive and social medicine. 18th edn. Jabalpur: M/s Banarsidas Bhanot 2007: p. 608-10.

[17] Johncy SS, Ajay KT, Dhanyakumar G, et al. Dust exposure and lung function impairment in construction workers. J Physiol Biomed Sci 2011;24(1):9-13.

[18] Oliver CL, Miracle-McMahill H, Littman AB, et al. Respiratory systems and lung function in workers in heavy and highway construction: a cross sectional study. Am J Ind Med 2001;40(1):73-86.
[19] Green DA, McAlphine G, Semple S, et al. Mineral dust exposure in young Indian adults: an effect on lung growth? Occup Environ Med 2008;65(5):306-10.

[20] Bagatin E, Juliano Y, Novo NF, et al. Influence of exposure time to silica and smoking on pulmonary function of workers in the ceramic and stone quarry industry. Amb Rev Assoc Med Bras 1991;37(2):85-90.

[21] Chia KS, Ng TP, Jeyaratnam J. Small airways function of silica-exposed workers. Am J Ind Med 1992;22(2):15562.

[22] Yang CY, Huang CC, Chiu HF, et al. Effect of occupational dust exposure on the respiratory health of Portland cement workers. J Toxicol Environ Health 1996;49(6):581-8.

[23] Al-Neaimi YI, Gomes J, Lloyd OL. Respiratory illnesses and ventilatory function among workers at a cement factory in a rapidly developing country. Occup Med (Lond) 2001;51(6):367-73.

[24] Meo SA, Al-Drees AM, Al-Masri AM, et al. Effect of duration of exposure to cement dust on respiratory function of non-smoking cement mill workers. Int J Environ Res Public Health 2013;10(1):390-8.

[25] Dehghan F, Mohammadi S, Sadeghi Z, et al. Respiratory complaints and spirometric parameters in tile and ceramic factory workers. Tanaffos 2009;8(4):19-25.

[26] Boskabady MH, Rezaiyan MK, Navabi I, et al. Workrelated respiratory symptoms and pulmonary function tests in Northeast Iranian (the city of Mashhad) carpenters. Clinics 2010;65(10):1003-7.

[27] Mathur ML, Dixit AK, Lakshminarayana J. Correlates of peak expiratory flow rate: a study of sand stone quarry workers in desert. Indian J Physiol Pharmacol 1996;40(4):340-4.

[28] Mariammal T, Jaisheeba AA, Sornaraj R. Work related respiratory symptoms and pulmonary function tests observed among construction and sanitary workers of Thoothukudi. International Journal of Pharm Tech Research 2012;4(3):1266-73. 